\title{
Comparison of carbetocin with other uterotonic agents in preventing postpartum hemorrhage
}

\author{
Belinda Carlisa* \\ Department of Obstetrics and Gynecology, Mauponggo Public Health Center, Nagekeo District, East Nusa Tenggara, \\ Indonesia
}

Received: 11 October 2018

Accepted: 27 October 2018

*Correspondence:

Dr. Belinda Carlisa,

E-mail: belinda.carlisa@gmail.com

Copyright: () the author(s), publisher and licensee Medip Academy. This is an open-access article distributed under the terms of the Creative Commons Attribution Non-Commercial License, which permits unrestricted non-commercial use, distribution, and reproduction in any medium, provided the original work is properly cited.

\begin{abstract}
Postpartum hemorrhage (PPH) is defined as blood loss of at least $500 \mathrm{ml}$ or more after vaginal delivery and $1000 \mathrm{ml}$ or more after abdominal delivery. It contributes up to $28 \%$ of maternal mortality worldwide and $30.3 \%$ of maternal death in Indonesia. $70 \%$ cases of PPH are caused by uterine atony. PPH can be prevented by doing routine use of uterotonic agents in active management of third stage of labour. Uterotonic agents that currently available are oxytocin, carbetocin, methylergometrine, syntometrine, misoprostol and carboprost. Carbetocin (a long-acting synthetic analogue of oxytocin) is a new drug which has stronger ability to induce uterine contraction than oxytocin. It does not induce hypertension like methylergometrine and syntometrine. Therefore, carbetocin can be considered as an alternative drug to oxytocin in women with severe preeclampsia. However, more studies are needed to assess the efficacy and safety of carbetocin for prevention of PPH in preeclamptic women. Compared to methylergometrine and syntometrine, carbetocin is more effective in reducing postpartum blood loss. Adverse effects like nausea and vomiting were lower in women treated with carbetocin. Compared to misoprostol, carbetocin is also superior in reducing blood loss. Adverse effects like shivering, fever and metallic taste were higher in women treated with misoprostol. Further studies are needed to assess the superiority between carbetocin and carboprost since there is no published literature yet regarding this topic. In conclusion, carbetocin is superior to other uterotonic agents in preventing postpartum hemorrhage with fewer adverse effects.
\end{abstract}

Keywords: Carbetocin, Postpartum hemorrhage, Uterotonic agents

\section{INTRODUCTION}

Postpartum hemorrhage (PPH) is the most important cause of maternal morbidity and mortality worldwide, and it contributes up to $28 \%$ of maternal deaths. ${ }^{1}$ In Indonesia, it is responsible for approximately $30.3 \%$ of maternal deaths. ${ }^{2} \mathrm{PPH}$ is defined as blood loss of greater than or equal to $500 \mathrm{ml}$ after vaginal delivery and greater than or equal to $1000 \mathrm{ml}$ after cesarean section, or any blood loss that cause hemodynamic instability after delivery. ${ }^{3-5}$ The most common cause of PPH is uterine atony and it accounts for $70 \%$ of cases. ${ }^{5,6}$ Uterotonic agents are routinely used in active management of third stage of labour for preventing PPH. It acts by enhancing natural uterine contraction and retraction during third stage of labour. ${ }^{7}$ Uterotonic agents that currently available are oxytocin, carbetocin, ergot alkaloids (such as ergonovine, syntometrine) and prostaglandins (such as misoprostol, carboprost). ${ }^{1,8,9}$

The most commonly used uterotonic agent for prevention of PPH is oxytocin. However, recently a lot of scientist showed interest to conduct research about carbetocin. It is a long-acting synthetic analogue of oxytocin which has a stronger ability to induce uterine contraction. Thus make it considered to be more effective than oxytocin in 
preventing PPH. $^{1}$ Several studies have reported that carbetocin decreases the need for additional uterotonic agents compared to oxytocin. ${ }^{7,10,11}$

Moreover, studies from Reyes et al and Nucci et al showed that carbetocin had similar safety profile with oxytocin in preventing PPH in women with severe preeclampsia. $^{12,13}$ Therefore, the author is interested to write this review article to compare the efficacy of carbetocin with other uterotonic agents in preventing postpartum hemorrhage using recent evidence.

\section{POSTPARTUM HEMORRHAGE (PPH)}

\section{Definition}

Postpartum hemorrhage (PPH) is defined as blood loss of greater than or equal to $500 \mathrm{ml}$ after vaginal delivery and greater than or equal to $1000 \mathrm{ml}$ after abdominal delivery or any blood loss that causes hemodynamic instability after delivery. ${ }^{3-5}$ PPH that occurs in the first 24 hours after delivery is defined as primary PPH while between
24 hours and 6 weeks after delivery is defined as secondary PPH. ${ }^{14,15}$

\section{Etiology}

Etiology of PPH is often referred as the four T; tone (uterine atony), tissue (retained placenta), trauma (laceration of genital tract), and thrombin (coagulopathy). ${ }^{3,9}$ Among these etiology, $70 \%$ of cases are caused by uterine atony. 5,6

\section{Prevention}

Prevention of PPH can be done by doing active management of the third stage of labor routinely. This protocol consists of 3 procedures; the use of uterotonic agents just after the birth of baby, controlled cord traction and uterine massage. ${ }^{3,5,16}$ Uterotonic agents that currently available for preventing PPH are oxytocin, carbetocin, methylergometrine, syntometrine, misoprostol and carboprost. $^{7}$ Pharmacology of these drugs is shown in Table 1.

Table 1: Pharmacology of all uterotonic agents in preventing postpartum hemorrhage.

\begin{tabular}{|c|c|c|c|c|c|}
\hline Drug & Dose and route & Onset of action & $\begin{array}{l}\text { Duration of } \\
\text { action }\end{array}$ & Side effects & Contraindications \\
\hline Oxytocin ${ }^{3,5,16,17}$ & $\begin{array}{l}10 \mathrm{IU} \text { im or } 5- \\
10 \mathrm{IU} \text { by slow } \\
\text { iv injection }\end{array}$ & 2-3 minutes & $15-30$ minutes & $\begin{array}{l}\text { Hypotension, } \\
\text { myocardial ischemia, } \\
\text { arrhythmias, nausea, } \\
\text { vomiting, headache, } \\
\text { flushing, and release of } \\
\text { atrial and brain } \\
\text { natriuretic }\end{array}$ & Unknown \\
\hline Carbetocin ${ }^{5,8,18}$ & $100 \mu \mathrm{g}$ iv or im & 2 minutes & $\begin{array}{l}2-4 \text { hours after } \\
\text { iv injection, 6- } \\
120 \text { minutes } \\
\text { after im } \\
\text { injection }\end{array}$ & $\begin{array}{l}\text { Nausea, vomiting, } \\
\text { abdominal pain, } \\
\text { hypotension, } \\
\text { headache, chilling } \\
\text { and pyrexia }\end{array}$ & $\begin{array}{l}\text { Uterine, vaginal or } \\
\text { cervical rupture }\end{array}$ \\
\hline Methylergometrine $e^{5,16}$ & $\begin{array}{l}0.2-0.5 \mathrm{mg} \text { oral, } \\
\mathrm{im}, \text { or iv }\end{array}$ & $\begin{array}{l}5-15 \text { minutes } \\
\text { after oral, } 2-5 \\
\text { minutes after im, } \\
\text { instantaneous } \\
\text { after iv }\end{array}$ & 2-4 hours & $\begin{array}{l}\text { Headache, nausea, } \\
\text { vomiting, dizziness, } \\
\text { hypertension, } \\
\text { coronary artery } \\
\text { spasm, intracerebral } \\
\text { hemorrhage }\end{array}$ & $\begin{array}{l}\text { Hypertension, } \\
\text { heart disease, } \\
\text { retained placenta, } \\
\text { preeclampsia, and } \\
\text { eclampsia }\end{array}$ \\
\hline Syntometrine $e^{5,8,19}$ & $\begin{array}{l}1 \mathrm{ml} \mathrm{im} \\
\text { (combination of } \\
5 \mathrm{IU} \text { oxytocin } \\
\text { plus } 0.5 \mathrm{mg} \\
\text { ergometrine) }\end{array}$ & 2-3 minutes & 3 hours & $\begin{array}{l}\text { Same as oxytocin and } \\
\text { ergometrine }\end{array}$ & $\begin{array}{l}\text { Same as oxytocin } \\
\text { and ergometrine }\end{array}$ \\
\hline Misoprostol $^{5,6,14}$ & $\begin{array}{l}400-600 \mu \mathrm{g} \\
\text { oral, sl, rectal }\end{array}$ & 3-5 minutes & 75 minutes & $\begin{array}{l}\text { Shivering, pyrexia, } \\
\text { nausea, vomiting and } \\
\text { diarrhea }\end{array}$ & Unknown \\
\hline Carboprost ${ }^{9,20}$ & $250 \mu \mathrm{g} \mathrm{im}$ & 20 minutes & 3 hours & $\begin{array}{l}\text { Nausea, vomiting, } \\
\text { diarrhea, headaches, } \\
\text { hypertension and } \\
\text { bronchial asthma }\end{array}$ & $\begin{array}{l}\text { Cardiac and } \\
\text { pulmonary disease }\end{array}$ \\
\hline
\end{tabular}




\section{COMPARISON OF CARBETOCIN WITH OTHER UTEROTONIC AGENTS IN PREVENTING POSTPARTUM HEMORRHAGE}

\section{Carbetocin versus oxytocin}

Attilakos et al in 2010 conducted a double-blind randomised single centre study to compare the effectiveness of carbetocin with oxytocin for prevention of PPH in low risk patients following cesarean section. 377 women were recruited and divided into two groups. 188 women received $100 \mu \mathrm{g}$ of intravenous carbetocin and 189 women received 5 units of intravenous oxytocin. The study found that carbetocin reduced the use of additional oxytocin when compared to oxytocin $(33.5 \%$ vs $45.5 \%, \mathrm{p}=0.023)$. Adverse effects were similar between two groups. ${ }^{10}$ This study is comparable to recent studies in 2016-2017. ${ }^{11,21-23}$

Mohamed Maged et al in 2015 conducted a prospective double-blind randomized study to compare the effectiveness of carbetocin with oxytocin for prevention of PPH in high risk patients following vaginal delivery. 200 women were recruited and divided into two groups. 100 women received $100 \mu \mathrm{g}$ of intramuscular carbetocin and 100 women received 5 units of intramuscular oxytocin. Amount of blood loss, the incidence of PPH, and the need for additional uterotonic agents were significantly lower in carbetocin group than in oxytocin group $(337.73 \pm 118.77 \mathrm{ml}$ vs $378 \pm 143.2 \mathrm{ml}, 4$ vs $16 \%, 23$ vs $37 \%, \mathrm{p}=0.03$ ). Adverse effects such as nausea, vomiting, flushing, dizziness, headache, shivering, metallic taste, dyspnea, palpitation and itching were similar between two groups. ${ }^{11}$

Hassan et al in 2017 conducted a comparative prospective case-controlled single centre study to compare the effectiveness of carbetocin with oxytocin for prevention of PPH in high risk patients following cesarean section. 200 women were recruited and divided into two groups. 100 women received $100 \mu \mathrm{g}$ of carbetocin intravenously and 100 women received 20 units of oxytocin in $500 \mathrm{ml}$ of $0.9 \% \mathrm{NaCl}$ solution as infusion $(150 \mathrm{ml} /$ hour $)$. They found that amount of blood loss and the need for additional uterotonic agents were significantly lower in carbetocin group than in oxytocin group $(557 \pm 304 \mathrm{ml}$ vs $716 \pm 377 \mathrm{ml}, \mathrm{p}=0.005 ; 18 \%$ vs $43 \%, \mathrm{p}<0.001)$. Adverse effects were similar between two groups. ${ }^{21}$

Two other studies by Taheripanah et al and Khalafalah et al also reached similar results. Taheripanah et al recruited 220 women following cesarean section to receive either $100 \mu \mathrm{g}$ of carbetocin intravenously or 30 units of oxytocin as infusion. Amount of blood loss, decrease in hemoglobin level and the need for additional uterotonic agents were significantly higher in oxytocin group than in carbetocin group $(552.6 \mathrm{ml}$ vs $430.68 \mathrm{ml}, \mathrm{p}<0.001 ; 2.05$ vs $1.01, \mathrm{p}=0.01 ; 36.4 \%$ vs $10 \%, \mathrm{p}<0.05) .{ }^{22}$ Khalafalah et al recruited 88 women following cesarean section to receive either $100 \mu \mathrm{g}$ of carbetocin intravenously or 20 units of oxytocin in $1000 \mathrm{ml}$ of $0.9 \% \mathrm{NaCl}$ solution as infusion (150ml/hour). They found that blood loss was significantly higher in oxytocin group than in carbetocin group (434.706 ml vs $366.477 \mathrm{ml}, \mathrm{p}=0.013){ }^{23}$

\section{Carbetocin versus oxytocin in severe preeclampsia}

Reyes et al in 2011 conducted a prospective double-blind randomized controlled trial to compare the use of oxytocin with carbetocin for prevention of $\mathrm{PPH}$ in women with severe preeclampsia. 60 women were recruited and divided into two groups to receive either carbetocin $(100 \mu \mathrm{g}$ diluted in $10 \mathrm{ml}$ of Ringer's lactate solution) or oxytocin (20 units diluted in $1000 \mathrm{ml}$ of Ringer's lactate solution) intravenously following either vaginal delivery or cesarean section. The study found that carbetocin had similar efficacy and safety with oxytocin in preventing $\mathrm{PPH}$ in women with severe preeclampsia. It did not induce hypertension or oligouria. ${ }^{12}$ These findings are in accordance with the recent study by Nucci et al in $2016 .{ }^{13}$

\section{Carbetocin versus methylergometrine}

A quasi experimental study by Boonkoonchanok et al in 2017 compared the effectiveness between $0.1 \mathrm{mg}$ of intravenous carbetocin and $0.2 \mathrm{mg}$ of intravenous methylergometrine maleate for prevention of PPH in low risk patients following vaginal delivery. 64 women were recruited, 32 in each group. They found that postpartum blood loss was significantly lower in carbetocin group than in methylergometrine maleate group (246.91 ml vs $312.53 \mathrm{ml}, \mathrm{p}=0.038$ ). Adverse effects like nausea and vomiting were found only in methylergometrine maleate group but none in carbetocin group. ${ }^{24}$

\section{Carbetocin versus syntometrine}

Askar et al in 2011, conducted a prospective double-blind randomized controlled study to compare the effectiveness between $100 \mu \mathrm{g}$ of intramuscular carbetocin and $1 \mathrm{ml}$ of intramuscular syntometrine (containing 5 units of oxytocin and $0.5 \mathrm{mg}$ ergometrine) for prevention of $\mathrm{PPH}$ in low risk patients following vaginal delivery. 240 women were recruited, 120 in each group. They found that postpartum blood loss was significantly lower in carbetocin group than in syntometrine group $(224.6 \pm 110.6 \mathrm{ml}$ vs $306.1 \pm 95.65 \mathrm{ml}, \mathrm{p}<0.01)$. Adverse effects like nausea and vomiting were significantly lower in carbetocin group than in syntometrine group $(\mathrm{p}<0.05)$ while hypertension was found only in syntometrine group but none in carbetocin group. ${ }^{25}$

Those findings are comparable with another study by Samimi et al. in 2013. They recruited 200 women following vaginal delivery to receive either $100 \mu \mathrm{g}$ of intramuscular carbetocin or $1 \mathrm{ml}$ of intramuscular syntometrine (containing 5 units of oxytocin and $0.2 \mathrm{mg}$ ergometrine). The study found that mean value of hemoglobin drop and the need for additional uterotonic 
agents were significantly lower in carbetocin group than in syntometrine group $(0.39 \mathrm{~g} / \mathrm{dl}$ vs $1.04 \mathrm{~g} / \mathrm{dl}, \mathrm{p}<0.001$; $1 \%$ vs $11 \%, \mathrm{p}=0.002)$. Adverse effects like nausea, abdominal pain and chill were lower in carbetocin group although the differences were not statistically significant. ${ }^{8}$

Mohamed Maged et al in 2016 conducted a double-blind randomized study to compare the effectiveness between carbetocin and syntometrine for prevention of PPH in 300 women following cesarean section. 150 women received $100 \mu \mathrm{g}$ of intravenous carbetocin and 150 women received $1 \mathrm{ml}$ of intramuscular syntometrine (containing 5 units of oxytocin and $0.2 \mathrm{mg}$ ergometrine). They found that the incidence of PPH and the need for additional uterotonic agents were significantly lower in carbetocin group than in syntometrine group $(2.7 \%$ vs $10 \%$, p $<0.001 ; 3.3 \%$ vs $17.3 \%$, p <0.001). But, there were no significant difference regarding side effects like nausea, vomiting and shivering between two groups. ${ }^{26}$

\section{Carbetocin versus misoprostol}

In 2016 Elbohoty et al conducted a double-blind randomized controlled trial to compare the effectiveness and safety of carbetocin, misoprostol, and oxytocin for prevention of PPH following cesarean section. 263 women were recruited and divided into three groups; Group I (88 women received $100 \mu \mathrm{g}$ of carbetocin in $1000 \mathrm{ml}$ of $0.9 \% \mathrm{NaCl}$ solution administered intravenously), Group II (89 women received $400 \mu \mathrm{g}$ of sublingual misoprostol tablets) and Group III (86 women received 10 units of oxytocin in $1000 \mathrm{ml}$ of $0.9 \% \mathrm{NaCl}$ solution administered intravenously and additionally received 20 units of oxytocin in $500 \mathrm{ml}$ of $0.9 \% \mathrm{NaCl}$ solution as infusion over 4 hours). The study found that the incidence of PPH and decrease in hemoglobin level were highest in misoprostol group (both $\mathrm{p}=0.001$ ), while the use of additional uterotonic agents was lowest in carbetocin group $(p=0.004)$. Adverse effects such as heat sensation, metallic taste, fever, and shivering were all highest in misoprostol group $(\mathrm{p}<0.05) .{ }^{7}$ These findings are in accordance with another study by Ibrahim et al. in 2017 that compares the use of $100 \mu \mathrm{g}$ of intravenous carbetocin with $600 \mu \mathrm{g}$ of sublingual misoprostol for prevention of $\mathrm{PPH}$ in women with severe preeclampsia following vaginal delivery. 60 women were recruited, 30 in each group. The study found that the incidence of PPH was significantly lower in carbetocin group than in misoprostol group (3\% vs $20 \%, \mathrm{p}=0.04$ ). Adverse effects such as abdominal pain, fever, metallic taste and shivering were also significantly lower in carbetocin group than in misoprostol group $(\mathrm{p}<0.05) .{ }^{27}$

Table 2: Comparison of carbetocin with oxytocin in preventing postpartum hemorrhage.

\begin{tabular}{|c|c|c|c|c|}
\hline Author & Sample & $\begin{array}{l}\text { Delivery } \\
\text { route }\end{array}$ & Drugs & Outcome \\
\hline Attilakos et al ${ }^{10}$ & 377 & $\mathrm{CS}$ & $\begin{array}{l}\text { Carbetocin } 100 \mu \mathrm{g} \text { iv } \\
\text { Oxytocin } 5 \mathrm{IU} \text { iv }\end{array}$ & $\begin{array}{l}\text { The need for additional uterotonic agents was } \\
\text { significantly lower in carbetocin group }(\mathrm{p}=0.023) \text {. } \\
\text { Adverse effects were similar between two groups. }\end{array}$ \\
\hline Maged $\mathrm{M}$ et al ${ }^{11}$ & 200 & VD & $\begin{array}{l}\text { Carbetocin } 100 \mu \mathrm{g} \mathrm{im} \\
\text { Oxytocin } 5 \mathrm{IU} \text { im }\end{array}$ & $\begin{array}{l}\text { Amount of blood loss, the incidence of } \mathrm{PPH} \text {, and the } \\
\text { need for additional uterotonic agents were } \\
\text { significantly lower in carbetocin group ( } \mathrm{p}=0.03 \text { ). } \\
\text { Adverse effects were similar between two groups. }\end{array}$ \\
\hline Hassan et $\mathrm{al}^{21}$ & 200 & CS & $\begin{array}{l}\text { Carbetocin } 100 \mu \mathrm{g} \text { iv } \\
\text { Oxytocin } 20 \mathrm{IU} \text { in } 500 \\
\mathrm{ml} \text { of } 0.9 \% \mathrm{NaCl} \text { iv } \\
(150 \mathrm{ml} / \text { hour })\end{array}$ & $\begin{array}{l}\text { Amount of blood loss and the need for additional } \\
\text { uterotonic agents were significantly lower in } \\
\text { carbetocin group ( } \mathrm{p}=0.005, \mathrm{p}<0.001) \text {. Adverse } \\
\text { effects were similar between two groups. }\end{array}$ \\
\hline Taheripanah et $\mathrm{al}^{22}$ & 220 & $\mathrm{CS}$ & $\begin{array}{l}\text { Carbetocin } 100 \mu \mathrm{g} \text { iv } \\
\text { Oxytocin } 30 \mathrm{IU} \text { in } 1000 \\
\mathrm{ml} \text { of } 0.9 \% \mathrm{NaCl} \text { iv }\end{array}$ & $\begin{array}{l}\text { Amount of blood loss decrease in hemoglobin level } \\
\text { and the need for additional uterotonic agents were } \\
\text { significantly lower in carbetocin group ( } p<0.001 \text {, } \\
p=0.01, p<0.05)\end{array}$ \\
\hline Khalafalah et $\mathrm{al}^{23}$ & 88 & $\mathrm{CS}$ & $\begin{array}{l}\text { Carbetocin } 100 \mu \mathrm{g} \text { iv } \\
\text { Oxytocin } 20 \mathrm{IU} \text { in } \\
1000 \mathrm{ml} \text { of } 0.9 \% \mathrm{NaCl} \\
\text { iv }(150 \mathrm{ml} / \text { hour })\end{array}$ & $\begin{array}{l}\text { Amount of blood loss was significantly lower in } \\
\text { carbetocin group }(\mathrm{p}=0.013) \text {. }\end{array}$ \\
\hline Reyes et $\mathrm{al}^{12}$ & 60 & $\begin{array}{l}\text { CS } \\
\mathrm{VD}\end{array}$ & $\begin{array}{l}\text { Carbetocin } 100 \mu \mathrm{g} \text { in } 10 \\
\text { ml Ringer's lactate iv } \\
\text { Oxytocin } 20 \mathrm{IU} \text { in } \\
1000 \mathrm{ml} \text { of Ringer's } \\
\text { lactate iv ( } 125 \mathrm{ml} / \text { hour })\end{array}$ & $\begin{array}{l}\text { Carbetocin had similar efficacy and safety with } \\
\text { oxytocin in preventing PPH in women with severe } \\
\text { preeclampsia. }\end{array}$ \\
\hline Nucci et al ${ }^{13}$ & 60 & $\mathrm{CS}$ & $\begin{array}{l}\text { Carbetocin } 100 \mu \mathrm{g} \text { iv } \\
\text { Oxytocin } 5 \mathrm{IU} \text { iv }\end{array}$ & $\begin{array}{l}\text { Carbetocin had similar efficacy and safety with } \\
\text { oxytocin in preventing PPH in women with severe } \\
\text { preeclampsia. }\end{array}$ \\
\hline
\end{tabular}

Abbreviations: $C S=$ cesarean section; $V D=$ vaginal delivery; $I U=$ international unit; im=intramuscular administration; iv=intravenous administration; sl=sublingual administration. 
Table 3: Comparison of carbetocin with other uterotonic agents in preventing postpartum hemorrhage.

\begin{tabular}{|c|c|c|c|c|}
\hline Author & Sample & $\begin{array}{l}\text { Delivery } \\
\text { route }\end{array}$ & Drugs & Outcome \\
\hline Boonkoonchanok et $\mathrm{al}^{24}$ & 64 & VD & $\begin{array}{l}\text { Carbetocin } 100 \mu \mathrm{g} \text { iv } \\
\text { Methylergometrine } \\
\text { maleate } 0.2 \mathrm{mg} \text { iv }\end{array}$ & $\begin{array}{l}\text { Postpartum blood loss was significantly lower in } \\
\text { carbetocin group }(\mathrm{p}=0.038) \text {. }\end{array}$ \\
\hline Askar et $\mathrm{al}^{25}$ & 240 & VD & $\begin{array}{l}\text { Carbetocin } 100 \mu \mathrm{g} \mathrm{im} \\
\text { Syntometrine } 1 \mathrm{ml} \mathrm{im}\end{array}$ & $\begin{array}{l}\text { Postpartum blood loss was significantly lower in } \\
\text { carbetocin group }(\mathrm{p}<0.01) \text {. Adverse effects were } \\
\text { significantly lower in carbetocin group }(\mathrm{p}<0.05) \text {. }\end{array}$ \\
\hline Samimi et $\mathrm{al}^{8}$ & 200 & VD & $\begin{array}{l}\text { Carbetocin } 100 \mu \mathrm{g} \mathrm{im} \\
\text { Syntometrine } 1 \mathrm{ml} \mathrm{im}\end{array}$ & $\begin{array}{l}\text { Mean value of hemoglobin drop and the need for } \\
\text { additional uterotonic agents were significantly lower } \\
\text { in carbetocin group ( } p<0.001, p=0.002) \text {. Adverse } \\
\text { effects were lower in carbetocin group although the } \\
\text { differences were not statistically significant. }\end{array}$ \\
\hline Maged $\mathrm{M}$ et $\mathrm{al}^{26}$ & 300 & $\mathrm{CS}$ & $\begin{array}{l}\text { Carbetocin } 100 \mu \mathrm{g} \text { iv } \\
\text { Syntometrine } 1 \mathrm{ml} \mathrm{im}\end{array}$ & $\begin{array}{l}\text { Incidence of PPH and the need for additional } \\
\text { uterotonic agents were significantly lower in } \\
\text { carbetocin group (both p <0.001). Adverse effects } \\
\text { were similar between two groups. }\end{array}$ \\
\hline Elbohoty et $\mathrm{al}^{7}$ & 263 & $\mathrm{CS}$ & $\begin{array}{l}\text { Carbetocin } 100 \mu \mathrm{g} \text { in } \\
10 \mathrm{ml} \text { of } 0.9 \% \mathrm{NaCl} \text { iv } \\
\text { Misoprostol } 400 \mu \mathrm{g} \text { sl } \\
\text { Oxytocin } 10 \mathrm{IU} \text { in } 10 \\
\mathrm{ml} \text { of } 0.9 \% \mathrm{NaCl} \text { iv }\end{array}$ & $\begin{array}{l}\text { Incidence of blood loss and decrease in hemoglobin } \\
\text { level were highest in misoprostol group compared to } \\
\text { carbetocin and oxytocin group (both } \mathrm{p}=0.001) \text {. The } \\
\text { need for additional uterotonic agents was lowest in } \\
\text { carbetocin group }(\mathrm{p}=0.004) \text {. Adverse effects were all } \\
\text { highest in misoprostol group }(\mathrm{p}<0.05) \text {. }\end{array}$ \\
\hline Ibrahim et $\mathrm{al}^{27}$ & 60 & VD & $\begin{array}{l}\text { Carbetocin } 100 \mu \mathrm{g} \text { iv } \\
\text { Misoprostol } 600 \mu \mathrm{g} \mathrm{sl}\end{array}$ & $\begin{array}{l}\text { Incidence of } \mathrm{PPH} \text { was significantly lower in } \\
\text { carbetocin group }(\mathrm{p}=0.04) \text {. Adverse effects were also } \\
\text { significantly lower in carbetocin group }(\mathrm{p}<0.05) \text {. }\end{array}$ \\
\hline Ali et $\mathrm{al}^{15}$ & 150 & $\mathrm{CS}$ & $\begin{array}{l}\text { Carbetocin } 100 \mu \mathrm{g} \text { iv } \\
\text { Oxytocin } 20 \mathrm{IU} \text { in } \\
1000 \mathrm{ml} \text { of } 0.9 \% \mathrm{NaCl} \\
\text { iv Misoprostol } 400 \mu \mathrm{g} \\
\text { rectal }\end{array}$ & $\begin{array}{l}\text { Incidence of PPH, the need for additional uterotonic } \\
\text { agents, blood transfusion, and decrease in } \\
\text { hemoglobin level were all significantly lower in } \\
\text { carbetocin group ( } \mathrm{p}<0.001, \mathrm{p}=0.02, \mathrm{p}<0.0001 \text {, p } \\
<0.05) \text {. }\end{array}$ \\
\hline
\end{tabular}

Abbreviations: $C S=$ cesarean section; $\mathrm{VD}=$ vaginal delivery; $\mathrm{IU}=$ international unit; im=intramuscular administration; iv=intravenous administration; sl=sublingual administration.

Latest study in 2018 by Ali et al compares the efficacy of carbetocin with oxytocin and rectal misoprostol for prevention of $\mathrm{PPH}$ in high risk patients following cesarean section. 150 women were recruited and divided into 3 groups; Group I (50 women received $100 \mu \mathrm{g}$ of carbetocin intravenously), Group II (50 women received 20 units of oxytocin in $1000 \mathrm{ml}$ of $0.9 \% \mathrm{NaCl}$ solution as infusion) and Group III (50 women received $400 \mu \mathrm{g}$ of misoprostol rectally). They found that the incidence of PPH, the need for additional uterotonic agents, blood transfusion, and decrease in hemoglobin level were all significantly lower in carbetocin group than in oxytocin group and misoprostol group $(\mathrm{p}<0.001, \mathrm{p}=0.02, \mathrm{p}$ $<0.0001, \mathrm{p}<0.05){ }^{15}$

\section{Carbetocin versus carboprost}

There is no published literature yet regarding the efficacy comparison between carbetocin and carboprost. All studies regarding efficacy comparison of carbetocin to other uterotonic agents in preventing postpartum hemorrhage are summarized in Table 2 and Table 3.

\section{CONCLUSION}

Carbetocin is superior to oxytocin in reducing postpartum hemorrhage and the need for additional uterotonic agents. Regarding adverse effects, carbetocin has similar adverse effects and safety profile with oxytocin. Carbetocin is also reported to be more effective than methylergometrine, syntometrine, and misoprostol. Adverse effects are fewer compared to these drugs.

There is very limited published literature regarding the efficacy of carbetocin in preventing postpartum hemorrhage in women with severe preeclampsia. Two studies reported that carbetocin is not associated with the development of oliguria or hypertension. Thus, carbetocin may be considered as a good alternative drug to oxytocin in women with severe preeclampsia. However, more studies are needed to assess the efficacy and safety of carbetocin in preeclamptic women. The author has not found any study that compares the efficacy of carbetocin to carboprost. Further studies are needed to assess the superiority between carbetocin and carboprost. 
Despite superiority of carbetocin to other uterotonic agents, oxytocin is still the drug of choice in preventing postpartum hemorrhage. This is due to its costeffectiveness and availability in most of health services in Indonesia since Indonesia is a developing country where health budget and infrastructure is often limited.

Funding: No funding sources

Conflict of interest: None declared

Ethical approval: Not required

\section{REFERENCES}

1. Seow KM, Chen KH, Wang PH, Lin YH, Hwang JL. Carbetocin versus oxytocin for prevention of postpartum hemorrhage in infertile women with twin pregnancy undergoing elective cesarean delivery. Taiwan J Obstet Gynecol. 2017;56(3):273-5.

2. Kemenkes RI [Ministry of Health, Republic of Indonesia]. Pusat Data dan Informasi [Center of Data and Information]. 2014.

3. Leduc D, Senikas V, Lalonde AB, Ballerman C, Biringer A, Delaney M, et al. Active Management of the Third Stage of Labour: Prevention and Treatment of Postpartum Hemorrhage. J Obstet Gynaecol Canada. 2009;31(10):980-93.

4. World Health Organization. WHO recommendations for the prevention and treatment of postpartum haemorrhage. Geneva, Switzerland: WHO Press; 2012. Available at: http://apps.who.int/iris/bitstream/10665/75411/1/978 9241548502_eng.pdf.

5. Gizzo S, Patrelli TS, Gangi S Di, Carrozzini M, Saccardi C, Zambon A, et al. Which uterotonic is better to prevent the postpartum hemorrhage? Latest news in terms of clinical efficacy, side effects, and contraindications: A systematic review. Reprod Sci. 2013;20(9):1011-9.

6. Alwani M, Singh S, Thakur R, Mishra S. A randomized study comparing rectally administered misoprostol after spinal anesthesia versus intramuscular oxytocin for prevention of postpartum hemorrhage in caesarean section. Int $\mathbf{J}$ Reprod Contraception, Obstet Gynecol. 2014;33(3):512-5.

7. Elbohoty AEH, Mohammed WE, Sweed M, Bahaa Eldin AM, Nabhan A, Abd-El-Maeboud KHI. Randomized controlled trial comparing carbetocin, misoprostol, and oxytocin for the prevention of postpartum hemorrhage following an elective cesarean delivery. Int $\mathrm{J}$ Gynecol Obstet. 2016;134(3):324-8.

8. Samimi M, Imani-Harsini A, Abedzadeh-Kalahroudi M. Carbetocin vs. syntometrine in prevention of postpartum hemorrhage: a double blind randomized control trial. Iran Red Crescent Med J. 2013;15(9):817-22.

9. Bai J, Sun Q, Zhai H. A comparison of oxytocin and carboprost tromethamine in the prevention of postpartum hemorrhage in high-risk patients undergoing cesarean delivery. Exp Ther Med. 2014;7(1):46-50.

10. Attilakos G, Psaroudakis D, Ash J, Buchanan R, Winter C, Donald F, et al. Carbetocin versus oxytocin for the prevention of postpartum haemorrhage following caesarean section: The results of a double-blind randomised trial. BJOG An Int J Obstet Gynaecol. 2010;117(8):929-36.

11. Maged AM, Hassan AM, Shehata NA. Carbetocin versus oxytocin for prevention of postpartum hemorrhage after vaginal delivery in high risk women. J Matern Neonatal Med. 2015;29(4):532-6.

12. Reyes OA, Gonzalez GM. Carbetocin versus oxytocin for prevention of postpartum hemorrhage in patients with severe preeclampsia: a double-blind randomized controlled trial. J Obstet Gynaecol Canada. 2011;33(11):1099-104.

13. Nucci B, Aya AGM, Aubry E, Ripart J. Carbetocin for prevention of postcesarean hemorrhage in women with severe preeclampsia: a before-after cohort comparison with oxytocin. J Clin Anesth. 2016;35:321-5.

14. Aziz S, Kazi S, Haq G, Soomro N. Oral misoprostol versus intramuscular oxytocin in the active management of the third stage of labour. J Pak Med Assoc. 2014;64(4):428-32.

15. Ali AEAE, Nasr AAM, Ahmed HH, Rasheedy MIE, Badawy M, Nasr AAM. Carbetocin versus Oxytocin and Misoprostol in prevention of atonic post-partum hemorrhage in high risk patients planed for cesarean delivery. Int J Reprod Contracept Obstet Gynecol. 2018;7(1):10-4.

16. Ramya KS, Shivanna S, Gopal N. Intravenous methergin versus intramuscular oxytocin in active management of third stage labour. Int $\mathrm{J}$ Recent Trends Sci Technol. 2015;14:260-4.

17. Mohamed HF, Mustafa GF, Ibrahim MA, Stefanos GE. Comparative study between intravenous bolus dose of carbetocin versus oxytocin during cesarean delivery in healthy parturients on blood loss: a randomized control trial. Med J Cairo Univ. 2015;83(2):167-72.

18. Rath W. Prevention of postpartum haemorrhage with the oxytocin analogue carbetocin. Eur J Obstet Gynecol Reprod Biol. 2009;147(1):15-20.

19. Government of South Australia. Ergot derivatives: prophylaxis for third stage management and postpartum haemorrhage. South Aust Perinat Pract Guidelines. 2016. Available at: http://www.sahealth.sa.gov.au/wps/wcm/connect/pub lic+content/sa+health+internet/resources/policies/erg ot+derivatives+prophylaxis+for+third+stage+manag ement+and+postpartum+haemorrhage++ sa+perinatal+practice+guidelines.

20. Government of South Australia. Clinical Guideline Prostaglandin Analogues for Major Postpartum Haemorrhage. South Aust Perinat Pract Guidelines. $2016 . \quad$ Available at: http://www.sahealth.sa.gov.au/wps/wcm/connect/pub lic+content/sa+health+internet/resources/policies/pro 
staglandin+analogues+for+postpartum+haemorrhage +--perinatal+practice+guidelines.

21. Hassan FI, Ahmad AA, Khaled MM, Diwer YM. Comparative study between carbetocin versus oxytocin in prevention of post-partum haemorrhage following caesarean section in high-risk pregnancies. Med J Cairo Univ. 2017;85(4):1469-75.

22. Taheripanah R, Shoman A, Karimzadeh M, Zamaniyan M, Malih N. Efficacy of oxytocin versus carbetocin in prevention of postpartum hemorrhage after cesarean section under general anesthesia: a prospective randomized clinical trial. J Matern Fetal Neonatal Med. 2018;31(21):2807-12.

23. Khalafalah MM. Oxytocin vs carbetocin in management of $3^{\text {rd }}$ stage at risk of PPH. MOJ Women's Heal. 2017;5(4):5.

24. Boonkoonchanok Y, Suthutvoravut S. Comparison of postpartum blood loss between intravenous carbetocin and intravenous methylergometrine maleate administered immediately at the third stage of labor. Ramathibodi Med J. 2017;40:1-7.
25. Askar AA, Ismail MT, Abo El-Ezz A, Rabie NH. Carbetocin versus syntometrine in the management of third stage of labor following vaginal delivery. Arch Gynecol Obstet. 2011;284(6):1359-65.

26. Mohamed Maged A, Ragab AS, Elnassery N, Ai Mostafa W, Dahab S, Kotb A. Carbetocin versus syntometrine for prevention of postpartum hemorrhage after cesarean section. J Matern Neonatal Med. 2016;30(8):962-6.

27. Ibrahim KAAM, Saad AS. Prevention of postpartum haemorrhage in patients with severe preeclampsia using carbetocin versus misoprostol. Apollo Med. 2017;14(2):117-22.

Cite this article as: Carlisa B. Comparison of carbetocin with other uterotonic agents in preventing postpartum hemorrhage. Int J Reprod Contracept Obstet Gynecol 2018;7:5207-13. 